\title{
A Study on Significance of Competence of Services Provider in Knowledge- Based Service Marketing
}

\section{OPEN ACCESS}

Manuscript ID:

COM-2021-09034125

Volume: 9

Issue: 3

Month: July

Year: 2021

E-ISSN: 2582-6190

Received: 23.04.2021

Accepted: 25.05.2021

Published: 01.07.2021

Citation:

Ponraj, P., and T.P. Ramprasad. "A Study on Significance of Competence of Services Provider in KnowledgeBased Service Marketing." ComFin Research, vol. 9, no. 3, 2021, pp. 7-10.

\section{DOI:}

https://doi.org/10.34293/ commerce.v9i3.4125

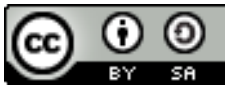

This work is licensed under a Creative Commons AttributionShareAlike 4.0 International License

\section{P. Ponraj}

Assistant Professor, Department of Commerce \& Research Centre

Sourashtra College (A), Madurai, Tamil Nadu, India

\section{T.P. Ramprasad}

Assistant Professor, Department of Commerce \& Research Centre

Sourashtra College (A), Madurai, Tamil Nadu, India

\section{Abstract}

In India BPO is a main source of knowledge based services. BPO offers many benefits, It aids in cost reduction by lowering $H R$ costs, such as wage bills, perks, employee benefits, and administrative overheads. Only the client is responsible for the cost of meaningful, high-quality work produced by Bookmarking knowledge-based services is a complicated process with numerous important considerations and the objective of the study is to know significance of competence of the service provider in knowledge-based services for this data has been collected from 30 sample respondents, SPSS package has been used to derive statistical inference.

Keywords: BPO, Knowledge based services, Service provider, Competence, Book marking

\section{Introduction}

The world today is rapidly transitioning from an industrial to a knowledgebased economy. Knowledge intensity exists in the knowledge economy, where efficient manufacturing is based on information and know-how a highly regarded, The key to success in the information economy and knowledge society is a skilled workforce. Knowledge workers refer to the knowledge professionals who work in the knowledge economy. Workers with higher degrees of education are known as knowledge workers, and their employment is the result of their abilities. The cycle time for introducing products and services has shrunk as global business has gotten more competitive. Customers expect a high level of service quality. As a result of the lack of reaction, businesses have created methods and business models that improve operational efficiency. Furthermore, these business models provide strategic value to the products and services they provide. Knowledge process outsourcing, or KPO, is the term for this phenomenon. Offshoring of knowledge-intensive business operations that require specific domain expertise is known as Knowledge Process Outsourcing. $\mathrm{KPO}$, or Knowledge Process Outsourcing, is the result of the evolution and maturity of the Indian BPO business. BPO is becoming stratified according to the level of expertise and knowledge required for the work. The cycle time for developing new products and services has shrunk as global industry has gotten more competitive. Customers expect a high level of service quality. 


\section{Objective of the Study}

- To know the Profile of service provider (BPO)

- To Analyse the significance of competence of the service providers in knowledge-based service marketing.

\section{Collection of Data}

The present study is based on both primary and secondary data. The required primary data were collected through the structured questionnaire. In this study a pre-test was conducted among 30 respondents according to the result of the pre-test and the opinion of the respondents surveyed. The researcher weeded out the unwanted questions and the suitable modifications was made in the questionnaire. The required secondary data were collected through newspapers, magazines, journals and web portals.

Table 1: Place of Business

\begin{tabular}{|l|c|c|}
\hline \multicolumn{1}{|c|}{ Location } & No. of respondents & $\mathbf{\%}$ \\
\hline Bangalore & 10 & 33.3 \\
\hline Chennai & 11 & 36.7 \\
\hline Hyderabad & 9 & 30.0 \\
\hline Total & 30 & 100 \\
\hline
\end{tabular}

Inference: Majority $36.7 \%$ of the sample respondents belongs to Chennai city.

Table 2: Type of Services

\begin{tabular}{|l|c|c|}
\hline \multicolumn{1}{|c|}{ Type of services } & No of respondents & $\mathbf{\%}$ \\
\hline Administration & 9 & 30.0 \\
\hline Customer Care & 10 & 33.3 \\
\hline Human Resource & 6 & 20.0 \\
\hline Finance \& Payment & 5 & 16.7 \\
\hline \multicolumn{1}{|c|}{ Total } & 30 & 100 \\
\hline
\end{tabular}

Inference: Majority $33.3 \%$ of the sample respondents service type is customer care.

Table 3: Business Experience

\begin{tabular}{|l|c|c|}
\hline Business Experience & No. of respondents & $\mathbf{\%}$ \\
\hline Up to 5 years & 9 & 30.0 \\
\hline 6-9 years & 10 & 33.3 \\
\hline 10-12 years & 11 & 36.7 \\
\hline \multicolumn{1}{|c|}{ Total } & 30 & 100 \\
\hline
\end{tabular}

Inference: Majority $36.7 \%$ of the sample respondent's business experience is about 10-12 years.
Table 4: Competence of the Service Providers in Knowledge-Based Service Marketing

\begin{tabular}{|l|c|c|c|}
\hline \multicolumn{1}{|c|}{ Options } & Mean & S. D. & Rank \\
\hline $\begin{array}{l}\text { Business Process } \\
\text { Management (BPM) }\end{array}$ & 11.1 & 2.11 & V \\
\hline $\begin{array}{l}\text { Outsourcing Management } \\
\text { (OMC) }\end{array}$ & 9.6 & 2.38 & II \\
\hline $\begin{array}{l}\text { Information Technology } \\
\text { Management Competence } \\
\text { (ITMC) }\end{array}$ & 9.9 & 2.37 & III \\
\hline $\begin{array}{l}\text { Human Resource } \\
\text { Management Competence } \\
\text { (HRMC) }\end{array}$ & 9.7 & 2.19 & IV \\
\hline $\begin{array}{l}\text { Relationship Management } \\
\text { Competence (RELMC) }\end{array}$ & 10.4 & 2.45 & I \\
\hline
\end{tabular}

From the table 4, it is observed that highest mean score 11.1 secured by Business Process Management (BPM), second highest mean score 10.4 mean is secured by Relationship Management Competence (RELMC) followed by Information technology management competence (ITMC) secured 9.9.

Table 5: Relationship Between Place of Business and Perception Score - Kruskal Wallis Test

\begin{tabular}{|l|c|c|c|}
\hline \multicolumn{1}{|c|}{ Options } & $\begin{array}{c}\text { Chi } \\
\text { square }\end{array}$ & $\begin{array}{c}\text { Asymp. } \\
\text { Sig }\end{array}$ & Result \\
\hline $\begin{array}{l}\text { Business Process } \\
\text { Management (BPM) }\end{array}$ & 0.154 & 0.926 & NS \\
\hline $\begin{array}{l}\text { Outsourcing } \\
\text { Management (OMC) }\end{array}$ & 0.935 & 0.627 & NS \\
\hline $\begin{array}{l}\text { Information Technology } \\
\text { Management } \\
\text { Competence (ITMC) }\end{array}$ & 2.194 & 0.334 & NS \\
\hline $\begin{array}{l}\text { Human Resource } \\
\text { Management } \\
\text { Competence (HRMC) }\end{array}$ & 0.080 & 0.961 & NS \\
\hline $\begin{array}{l}\text { Relationship } \\
\text { Management } \\
\text { Competence (RELMC) }\end{array}$ & 3.265 & 0.195 & NS \\
\hline
\end{tabular}

NS - Not Significant

From the table 5, it is observed that there is no significant relationship between place of business and perception score. Since the level of significance is more than 0.05 null hypothesis accepted. Hence it is concluded that place of business has no significant relationship between perception score of competencies. 
Table 6: Relationship between Type of Service and Perception Score - Kruskal Wallis Test

\begin{tabular}{|l|c|c|c|}
\hline \multicolumn{1}{|c|}{ Options } & $\begin{array}{c}\text { Chi } \\
\text { square }\end{array}$ & $\begin{array}{c}\text { Asymp. } \\
\text { Sig }\end{array}$ & Result \\
\hline $\begin{array}{l}\text { Business Process } \\
\text { Management (BPM) }\end{array}$ & 1.348 & 0.718 & NS \\
\hline $\begin{array}{l}\text { Outsourcing } \\
\text { Management (OMC) }\end{array}$ & 3.170 & 0.366 & NS \\
\hline $\begin{array}{l}\text { Information Technology } \\
\text { Management } \\
\text { Competence (ITMC) }\end{array}$ & 0.576 & 0.902 & NS \\
\hline $\begin{array}{l}\text { Human Resource } \\
\text { Management } \\
\text { Competence (HRMC) }\end{array}$ & 1.495 & 0.683 & NS \\
\hline $\begin{array}{l}\text { Relationship } \\
\text { Management } \\
\text { Competence (RELMC) }\end{array}$ & 3.487 & 0.322 & NS \\
\hline
\end{tabular}

NS - Not Significant

From the table it is observed that there is no significant relationship between type of service and perception score. Since the level of significance is more than 0.05 null hypothesis accepted. Hence it is concluded that Type of Service has no significant relationship between perception score of competencies.

Table 7: Relationship between Number of Years of Service and Perception Score - Kruskal Wallis

\begin{tabular}{|l|c|c|c|}
\multicolumn{1}{|c|}{ Options } & $\begin{array}{c}\text { Chi } \\
\text { square }\end{array}$ & $\begin{array}{c}\text { Asymp. } \\
\text { Sig }\end{array}$ & Result \\
\hline $\begin{array}{l}\text { Business Process } \\
\text { Management (BPM) }\end{array}$ & 1.514 & 0.469 & NS \\
\hline $\begin{array}{l}\text { Outsourcing } \\
\text { Management (OMC) }\end{array}$ & 2.458 & 0.293 & NS \\
\hline $\begin{array}{l}\text { Information } \\
\text { Technology } \\
\text { Management } \\
\text { Competence (ITMC) }\end{array}$ & 1.872 & 0.392 & NS \\
\hline $\begin{array}{l}\text { Human Resource } \\
\text { Management } \\
\text { Competence (HRMC) }\end{array}$ & 2.711 & 0.258 & NS \\
\hline $\begin{array}{l}\text { Relationship } \\
\text { Management } \\
\text { Competence (RELMC) }\end{array}$ & 0.879 & 0.644 & NS \\
\hline \multicolumn{4}{|l|}{ NS - Not Significant }
\end{tabular}

From the table it is observed that there is no significant relationship between number of years of service and perception score. Since the level of significance is more than 0.05 null hypothesis accepted. Hence it is concluded that number of years of service has no significant relationship between perception score of competencies.

\section{Findings}

- Majority $36.7 \%$ of the sample respondents belongs to Chennai city.

- Majority $33.3 \%$ of the sample respondents service type is customer care.

- Majority $36.7 \%$ of the sample respondent's business experience is about 10-12 years.

There is no significant relationship between place of business and perception score. Since the level of significance is more than 0.05 null hypothesis accepted. Hence it is concluded that place of business has no significant relationship between perception score of competencies.

There is no significant relationship between type of business and perception score. since the level of significance is more than 0.05 null hypothesis accepted. Hence it is concluded that type of service has no significant relationship between perception score of competencies.

There is no significant relationship between number of years of service and perception score. Since the level of significance is more than 0.05 null hypothesis accepted. Hence it is concluded that number of years of service has no significant relationship between perception score of competencies.

\section{Conclusion}

Business process management and relationship management are two crucial skills that will aid the service provider in delivering BPO outcomes that meet the client's expectations. In order to strengthen business process management competency, the service provider must also have the foundational competencies of information technology management and human resource management. Competence of the service provider is not dependence on their location, experience and type of business but based on the performance of the service provider. 


\section{References}

Agarwal, Ranjana, and Syeedun Nisa. "Knowledge Process Outsourcing: India's Emergence as a Global Leader." Asian Social Science, vol. 5 , no. 1, 2009.

Kohlbacher, Florian. "Knowledge-based Marketing: Building and Sustaining Competitive Advantage through Knowledge Co-Creation." International Journal of Management and Decision Making, vol. 9, no. 6, 2009, pp. 617-645.

Kohlbacher, Florian. "Strategic Knowledgebased Marketing." International Journal of Knowledge Management Studies, vol. 3, no. $1 / 2,2009$.

Kshetri, Nir, and Nikhilesh Dholakia. "Offshoring of Healthcare Services: The Case of US-India
Trade in Medical Transcription Services." Journal of Health Organization and Management, vol. 25, no. 1, 2011, pp. 94-107. Plumb, Ion. "Managing Service Quality within the Knowledge-Based Economy: Opportunities and Challenges." Quality Management in Services, vol. 11, 2009, pp. 373-382.

Prasad, Rekha. "Knowledge Based Services with Information and Communication Technologies (ICT) Support - A Tool for Women Empowerment." The Public Sector Innovation Journal, vol. 13, no. 1, 2008.

Srithika, T.M., and Sanghamitra Bhattacharyya. "Measuring Value Progress in Outsourcing Organizations." Strategic Outsourcing: An International Journal, vol. 4, no. 2, 2011, pp. 112-130.

\section{Author Details}

P. Ponraj, Assistant Professor, Department of Commerce \& Research Centre, Sourashtra College (A), Madurai, Tamil Nadu, India

T.P. Ramprasad, Assistant Professor, Department of Commerce \& Research Centre, Sourashtra College (A), Madurai, Tamil Nadu, India 